\title{
TATA KELOLA DAN KINERJA KEUANGAN BADAN USAHA MILIK NEGARA (BUMN) GO PUBLIC PERIODE 2014-2018
}

\author{
Andika Dwi Pradito \\ Universitas Tidar \\ andika.pradito@gmail.com \\ Axel Giovanni \\ Universitas Tidar \\ axelgiovanni@untidar.ac.id \\ Devi Wahyu Utami \\ Universitas Tidar \\ deviwahyutami@gmail.com
}

\begin{abstract}
Abstrak: Tata Kelola Dan Kinerja Keuangan Badan Usaha Milik Negara (BUMN) Go Public Periode 2014-2018. Penelitian ini bertujuan untuk memberikan bukti empiris mengenai pengaruh tata kelola perusahaan terhadap kinerja keuangan Badan Usaha Milik Negara (BUMN) yang terdaftar di Bursa Efek Indonesia (BEI) selama periode 2014-2018. Sampel penelitian yang memenuhi kriteria berjumlah 12 Badan Usaha Milik Negara (BUMN). Alat analisis yang digunakan adalah regresi linear. Hasil penelitian memberikan bukti mengenai urgensi komite audit dalam tata kelola perusahaan. Penelitian ini juga menunjukan bahwa board size, board independence serta kepemilikan pemerintah tidak memiliki peran dalam menjelaskan variabilitas kinerja keuangan Badan Usaha Milik Negara (BUMN).
\end{abstract}

Kata kunci: Badan Usaha Milik Negara (BUMN), kinerja keuangan, tata kelola perusahaan

Abstract: Governance and Financial Performance of State-Owned Enterprises (SOEs) Go Public Period 2014-2018. This study aims to provide empirical evidence regarding the effect of corporate governance on the financial performance of State-Owned Enterprises (SOEs) listed on the Indonesia Stock Exchange (IDX) during the 2014-2018 period. Research samples that met the criteria totaled 12 State-Owned Enterprises (BUMN). The analytical tool used is linear regression. The results of the study provide evidence of the urgency of the audit committee in corporate governance. This study also shows that board size, board independence, and government ownership do not have a role in explaining the variability in the financial performance of SOEs.

Keywords: corporate governance, financial performance, state-owned enterprises (SOEs)

\section{PENDAHULUAN}

Kamus Besar Bahasa Indonesia (KBBI) mendefinisikan perusahaan sebagai organisasi berbadan hukum yang mengadakan transaksi atau usaha. Perusahaan juga dapat dikatakan sebagai suatu ikatan kontrak (nexus of contract) antara individual dimana salah satu pihak bertindak sebagai principal atau pemilik perusahaan, pihak lain bertindak sebagai agen (manager). Perusahaan dalam perspektif ekonomi menurut Carlton \& Perloff (2015) didefinisikan sebagai organisasi yang mentransformasikan atau mengubah input (tenaga kerja, bahan baku dan modal) menjadi output dalam bentuk barang atau jasa. Perusahaan dalam 


\section{Nominal: Barometer Riset Akuntansi dan Manajemen}

P-ISSN: 2303-2065 E-ISSN: 2502-5430

Volume 10 No 1 (2021)

perspektif ekonomi bertujuan untuk memperoleh keuntungan, they exist to make money. Perusahaan sebagai suatu ikatan kontrak dalam perspektif manajemen keuangan bertujuan untuk memaksimalkan nilai perusahaan atau memaksimalkan kekayaan pemegang saham. Keuntungan dan memaksimalkan nilai perusahaan hanya dapat diperoleh atau dicapai ketika perusahaan memiliki kinerja yang baik.

Kinerja entitas bisnis secara ringkas merupakan representasi dari kegiatan yang telah dilakukan oleh perusahaan pada periode tertentu. Studi empiris yang dilakukan oleh Putra \& Nuzula (2017) mendefinisikan kinerja perusahan sebagai bentuk komitmen perusahaan dalam mengimplementasikan good corporate governance. Pendapat lain diungkapkan oleh Taouab \& Issor (2019) bahwa kinerja terutama dalam konteks keuangan merupakan seperangkat indikator yang memberikan informasi mengenai tentang keberhasilan pencapaian tujuan keuangan perusahaan.

Kinerja keuangan dapat dikatakan sebagai aspek fundamental bagi keberlangsungan hidup perusahaan, Rashid (2018) menyatakan bahwa kinerja keuangan yang maksimal ditentukan oleh keseriusan perusahaan dalam menerapkan sistem tata kelola yang baik. Kondisi tersebut dapat direpresentasikan pada kinerja keuangan PT Krakatau Steel (Persero) Tbk. Berdasarkan data dari Bursa Efek Indonesia (BEI), kinerja keuangan yang diproksikan melalui return on asset (ROA) selama tahun 2014 hingga 2018 dapat dilihat direpresentasikan melalui grafik berikut:

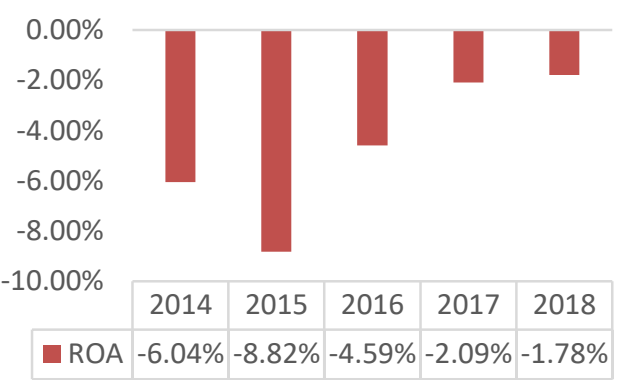

Gambar 1: Grafik Kinerja PT Krakatau Steel Sumber: Bursa Efek Indonesia

PT Krakatau Steel sebagai salah satu badan usaha milik negara (BUMN) yang seharusnya menjadi pemimpin industri baja tanah air, justru mencatatkan kerugian selama lima tahun berturut-turut. Kinerja keuangan yang kurang baik tersebut merupakan konsekuensi akibat lemahnya tata kelola perusahaan. CNN Indonesia menyatakan bahwa kasus yang menjerat direktur Krakatau Steel atas dugaan penerimaan suap pengadaan barang dan jasa pada Maret 2019 menjadi salah satu representasi dari lemahnya tata kelola di perusahaan tersebut. Kasus serupa juga menimpa beberapa perusahaan BUMN diantaranya yaitu kasus yang menjerat Direktur Utama PT Industri Telekomunikasi Indonesia sebagai tersangka atas dugaan korupsi pemberian suap pada proyek baggage handling system (BHS) milik PT 


\section{Nominal: Barometer Riset Akuntansi dan Manajemen}

P-ISSN: 2303-2065 E-ISSN: 2502-5430

Volume 10 No 1 (2021)

Angkasa Pura II, terjeratnya Direktur Utama PT Perusahaan Listrik Negara Tbk atas kasus suap proyek PLTU Riau-1 pada April 2019 dan terjeratnya Direktur Utama Perum Perikanan Indonesia (Perindo) dalam kasus suap impor ikan 2018. Fenomena tersebut tidak sejalan dengan peran Badan Usaha Milik Negara (BUMN) yang tertulis dalam Undang-Undang Republik Indonesia No 19 Tahun 2003 yaitu sebagai salah motor penggerak perekonomian nasional untuk mewujudkan kesejahteraan masyarakat (Undang-Undang Republik Indonesia Tentang Badan Usaha Milik Negara, 2003).

Tata Kelola perusahaan (corporate governance) merupakan suatu konsep bagaimana sebaiknya suatu perusahaan dikelola. Tujuan utama dari konsep ini adalah untuk memastikan bahwa perusahaan memiliki kinerja yang baik sehingga mampu mengingkatkan nilai kekayaan pemilik perusahaan (Wardani \& Juliani, 2018). Larcker \& Tayan (2016) mendefinisikan tata kelola perusahaan sebagai kumpulan mekanisme kontrol yang diadopsi oleh organisasi untuk mencegah manajer memiliki kepentingan sendiri terlibat dalam kegiatan yang merugikan kesejahteraan pemegang saham dan pemangku kepentingan.

Tata kelola perusahaan memberikan kontribusi metodologis terhadap kinerja perusahaan (Ciftci et al., 2019). Mekanisme tata kelola sangat dibutuhkan untuk meminimalisir masalah keagenan yang muncul karena adanya permasalahan kepentingan (agency problem) antara manajer (agent) dengan pemilik perusahaan (principal) (Utami \& Giovanni, 2020). Pertama, sebagai mekanisme tata kelola internal, dewan direksi memegang peran penting dalam memantau manajemen dan mengurangi masalah keagenan serta meminimalisir biaya agensi (Petchsakulwong \& Jansakul, 2017) dan karenanya dapat meningkatkan kinerja perusahaan (Akbar et al., 2016). Secara khusus, penelitian ini menyelidiki hubungan board characteristic yang diproksikan melalui board size dan board independence terhadap kinerja perusahaan (Palaniappan, 2017; Mishra and Kapil, 2018; Unda, Ahmed and Mather, 2019; Merendino and Melville, 2019). Dipandang dari kajian Resources Dependence Theory (RDT) semakin banyak anggota dewan maka semakin banyak pengalaman atau pengetahun dan akses sumber daya yang dimiliki perusahaan, sehingga efektivitas tata kelola semakin baik. Kedua, sebagai mekanisme tata kelola eksternal, struktur kepemilikan yang diproksikan melalui kepemilikan pemerintah (government ownership) menjadi faktor penentu kinerja perusahaan (Kao, Hodgkinson and Jaafar, 2019; Angela et al., 2019; Ahmed Haji, 2014). Kepemilikan 


\section{Nominal: Barometer Riset Akuntansi dan Manajemen \\ P-ISSN: 2303-2065 E-ISSN: 2502-5430 \\ Volume 10 No 1 (2021)}

pemerintah memberikan dampak signifikan atas akses sumber daya, sumber keuangan dan hak istimewa politik bagi perusahaan (Zhou, Gao, \& Zhao, 2016). Ketiga, audit committee yang diproksikan melalui audit committee size menjadi faktor penting dalam mekanisme tata kelola perusahaan (AlOkaily and Naueihed, 2019; Musallam, 2020; Ofoeda, 2017; Salehi, Tahervafaei and Tarighi, 2018; Zhou, Ansah and Maggina, 2018). Perusahaan dengan komite audit yang kompeten menurunkan probabilitas kinerja perusahaan yang buruk (Detthamrong et al., 2017). Dengan demikian, kepatuhan terhadap mekanisme tata kelola perusahaan dapat meminimalisir masalah keagenan dan biaya agensi serta memberikan kontribusi positif terhadap kinerja perusahaan (Akbar et al., 2016).

Urgensi tata kelola perusahaan sebagai salah satu faktor fundamental perusahaan belum diikuti oleh bukti empiris yang konsisten. Pernyataan tersebut dapat dibuktikan melaui studi empiris yang dilakukan oleh Petchsakulwong and Jansakul (2017), Buchdadi et al. (2019) dan Ciftci et al. (2019) yang menunjukkan bahwa tata kelola perusahaan yang diproksikan dengan board size memiliki hubungan positif dan signifikan terhadap kinerja perusahaan. Pendapat lain diungkapkan oleh Mohamed, Ahmad and Khai (2016) dan Pavić Kramarić et al. (2018) yang menyatakan bahwa board size memiliki pengaruh negatif dan signifikan terhadap kinerja perusahaan yang diproksikan melalui return on asset. Selanjutnya, hasil studi empiris yang dilakukan oleh H. Zhou et al. (2018) menyatakan bahwa board independence memiliki hubungan negatif dan signifikan terhadap kinerja keuangan perusahaan. Pendapat yang berbeda dinyatakan oleh Palaniappan G. (2017) dan Mishra \& Kapil (2018) bahwa board independence dan kinerja keuangan mempunyai hubungan positif dan signifikan. Hasil penelitian tersebut tidak sesuai dengan penelitian yang dilakukan oleh Buallay et al. (2017), Detthamrong, Chancharat and Vithessonthi (2017) dan Rashid (2018). yang menyatakan bahwa board independence tidak memiliki pengaruh terhadap kinerja keuangan. Kemudian, berdasarkan studi empiris yang dilakukan oleh Angela et al. (2019) menyatakan bahwa kepemilikan pemerintah memiliki hubungan negatif dan signifikan terhadap kinerja keuangan. Pendapat lain diungkapkan oleh Ahmed Haji (2014) bahwa government ownership tidak memiliki pengaruh yang signifikan terhadap kinerja keuangan. Berdasarkan hasil studi empiris yang dilakukan oleh Ofoeda (2017) dan Musallam (2020) menyatakan bahwa audit committee size memiliki hubungan positif dan signifikan terhadap kinerja keuangan perusahaan. Pendapat lain dinyatakan oleh 


\section{Nominal: Barometer Riset Akuntansi dan Manajemen}

P-ISSN: 2303-2065 E-ISSN: 2502-5430

Volume 10 No 1 (2021)

Aprinita (2016), Putra and Nuzula (2017), dan Salehi, Tahervafaei and Tarighi (2018) bahwa audit committee size tidak memiliki hubungan yang signifikan terhadap kinerja keuangan perusahaan. Sementara Al-Okaily \& Naueihed (2019) menyatakan bahwa audit committee size dan kinerja keuangan memiliki pengaruh positif dan signifikan pada perusahaan non-keluarga, dan tidak memiliki pengaruh yang signifikan pada perusahaan keluarga. Oleh karena itu, hasil penelitian yang berbeda menunjukkan bahwa masih diperlukan penelitian lebih lanjut mengenai keterkaitan tata kelola dengan kinerja perusahaan.

Penelitian ini bertujuan untuk memberikan bukti empiris mengenai pengaruh tata kelola perusahaan terhadap kinerja keuangan Badan Usaha Milik Negara (BUMN). Pertama, penelitian ini dilakukan untuk menguji kembali beberapa perbedaan hasil penelitian sebelumnya. Kedua, umumnya studi tata kelola perusahaan hanya mengkaji satu atau dua aspek tata kelola perusahaan. Secara lebih lanjut, penelitian ini memperluas penelitian sebelumnya dengan menggabungkan tiga aspek tata kelola secara bersama-sama yaitu board characteristic, ownership, dan audit committee dengan menguji secara empiris pengaruh board size, board independence, government ownership dan audit committee size terhadap kinerja keuangan perusahaan Badan Usaha Milik Negara (BUMN) pada periode 2014-2018.

\section{KAJIAN LITERATUR}

\section{Agency Theory}

Agency theory mendefinisikan perusahaan sebagai suatu ikatan kontrak (nexus of contract) antara pemilik perusahaan (principal) dan agent (jajaran manajemen) sebagai pihak yang diberi tanggung jawab untuk mengelola perusahaan dengan tujuan untuk memaksimalkan kekayaan pemilik perusahaan. Miles (2012) menyatakan bahwa "the agent is acting on behalf of the principal; the principal gives away some decision-making authority to agent". Asumsi utama dalam konteks makna dasar agency theory adalah the separation of ownership and control. Paradigma sentral dari agency theory dikemukakan oleh Jensen \& Meckling (1976) bahwa "the agent will not always act in the best interests of the principal". Paradigma sentral tersebut menghasilkan suatu konsep penting yaitu agency cost. Agency cost dapat didefinisikan sebagai suatu biaya yang harus dikeluarkan oleh pemilik perusahaan untuk memastikan bahwa jajaran manajemen (agent) perusahaan selalu bertindak sesuai kepentingan pemilik perusahaan (principal).

\section{Resource Dependency Theory}


Konsep resource dependency theory (RDT) menjelaskan bahwa suatu perusahaan harus dapat meminimalkan ketergantungan dan memperbanyak akses sumber daya terhadap lingkungan eksternal (Pfeffer \& Salancik, 1978). Resource dependency theory (RDT) sering dihubungkan dengan anggota dewan dimana jumlah dan komposisi anggota dewan disesuaikan dengan kebutuhan akan akses sumber daya serta ketergantungan terhadap lingkungan eksternal (Pfeffer, 1972). Dewan memberikan empat manfaat terhadap perusahaan, yaitu; informasi dalam bentuk saran maupun nasihat, akses informasi mengenai lingkungan yang berhubungan dengan industri perusahaan, akses prefrensi sumber daya, dan legitimasi (Pfeffer \& Salancik, 1978). Perusahaan akan memilih anggota dewan yang disesuaikan dengan strategi perusahaan dimana memperbanyak akses sumber daya dan meminimalkan ketergantungan terhadap lingkungan eksternal. Melalui resource dependency theory (RDT), dapat diasumsikan bahwa anggota dewan memiliki hubungan positif terhadap kinerja perusahaan (Buchdadi et al., 2019). Resource dependency theory (RDT) digunakan dalam menganalisis pengaruh jumlah anggota dewan perusahaan BUMN terhadap kinerja perusahaan.

\section{Board Size dan Kinerja Perusahaan}

Tata kelola perusahaan sangat kontradiktif dengan ukuran dewan (board size) yang dikaitkan dengan kinerja perusahaan (Palaniappan G., 2017). Board size merupakan jumlah dewan direksi yang menjabat dalam suatu perusahaan (Azis \& Hartono, 2017). Dewan memiliki dua fungsi utama yaitu (1) fungsi pemantauan yang dihubungkan dengan teori agensi; (2) fungsi menyediakan sumber daya yang dikaitkan dengan resource dependency theory (Unda et al., 2019). Resource dependency theory (RDT) mengasumsikan bahwa ukuran dewan memberikan kontribusi positif terhadap kinerja perusahaan (Buchdadi et al., 2019). Berdasarkan studi empiris yang dilakukan oleh Mohamed, Ahmad and Khai (2016) dan Pavić Kramarić et al. (2018) menyatakan bahwa board size memiliki pengaruh negatif dan signifikan terhadap kinerja perusahaan yang diproksikan melalui return on asset. Pendapat lain diungkapkan oleh Petchsakulwong and Jansakul (2017) dan Buchdadi et al. (2019) bahwa board size memiliki hubungan positif dan signifikan terhadap kinerja perusahaan. Pendapat tersebut sejalan dengan Ciftci et al. (2019) yang menyatakan bahwa peningkatan ukuran dewan akan meningkatkan return on asset (ROA). Semakin besar ukuran dewan akan meningkatkan monitoring terhadap manjemen sehingga manajemen akan selalu bertindak sesuai dengan kepentingan 


\section{Nominal: Barometer Riset Akuntansi dan Manajemen}

P-ISSN: 2303-2065 E-ISSN: 2502-5430

Volume 10 No 1 (2021)

pemilik, sehingga akan memberikan kontribusi positif terhadap kinerja perusahaan. Dengan demikian, hipotesis alternatif pertama yang diajukan dalam penelitian ini adalah:

H1. Board size berpengaruh positif terhadap kinerja keuangan perusahaan

\section{Board Independence dan Kinerja Perusahaan}

Board Independence didefinisikan sebagai anggota dewan yang tidak terafiliasi dengan pihak manajemen, anggota dewan lainnya dan pemegang saham pengendali, serta bebas dari hubungan bisnis yang dapat mempengaruhi kemampuannya untuk bertindak secara independen (Buchdadi et al., 2019). Dewan independen umumnya lebih efektif dan berfikir obyektif dibandingkan dengan dewan komisaris dan direksi (B. P. D. Putra, 2015). Berdasarkan studi empiris yang dilakukan oleh Darko et al. (2016) yang menganalisis pengaruh corporate governance terhadap kinerja perusahaan dengan sampel 20 perusahaan selama lima tahun, hasil penelitian menyatakan bahwa boards independence memiliki pengaruh negatif terhadap kinerja perusahaan. Hasil penelitian tersebut sesuai dengan pernyataan H. Zhou et al. (2018) bahwa board independence memiliki hubungan negatif terhadap kinerja keuangan perusahaan. Sedangkan menurut Buallay et al. (2017),
Detthamrong et al. (2017) dan Rashid (2018) menyatakan bahwa board independence tidak memiliki pengaruh terhadap kinerja keuangan. Pendapat lain diungkapkan oleh Palaniappan G. (2017) dan Mishra \& Kapil (2018) bahwa board independence mempunyai hubungan positif dan signifikan terhadap kinerja perusahaan. Perusahaan menunjuk dewan independen untuk memantau kinerja agent dan membantu mencapai kepentingan pemegang saham. Dewan independen yang ditunjuk akan melakukan monitoring terhadap manajer secara efektif untuk mengurangi biaya agensi (Mishra \& Kapil, (2018). Dengan demikian, semakin tinggi proporsi board independence akan meningkatkan kinerja perusahaan. Hipotesis alternatif kedua yang diajukan dalam penelitian ini adalah:

H2. Board independence berpengaruh positif terhadap kinerja keuangan perusahaan

\section{Government Ownership dan Kinerja Perusahaan}

Government ownership atau kepemilikan pemerintah adalah jumlah kepemilikan saham yang dimiliki pemerintah sebagai wakil negara pada suatu perusahaan (Angela et al., 2019). Dalam konsep teori agensi, pemisahan kepemilikan pemerintah bertujuan untuk melakukan kontrol dan monitoring terhadap manajer. Kepemilikan pemerintah dalam BUMN menjadi faktor 
penting penentu kinerja BUMN Pemerintah mempunyai proporsi kepemilikan besar di BUMN mempunyai peran yang besar pula dalam kegiatan operasional dan bertanggung jawab dalam mengelola serta mengatur perusahaan. Sejumlah penelitian telah dilakukan untuk mengetahui hubungan kepemilikan pemerintah terhadap kinerja perusahaan, Ahmed Haji (2014) menjelaskan bahwa terdapat hubungan yang tidak signifikan antara government ownership dengan kinerja perusahaan di Malaysia. Sedangkan menurut Angela et al. (2019) kepemilikan pemerintah memiliki hubungan negatif dan signifikan terhadap kinerja keuangan. Pendapat lain diungkapkan oleh Mohd Ghazali (2012) bahwa government ownership dan kinerja perusahaan memiliki hubungan yang positif. Dengan adanya kepemilikan pemerintah, perusahaan mendapatkan keuntungan berupa akses sumber daya, sumber keuangan dan hak istimewa politik bagi perusahaan (Zhou, Gao, \& Zhao, 2017). Dengan demikian porsi kepemilikan pemerintah yang besar akan menguntungkan dengan adanya penyediaan sumber daya dan otoritas yang lebih besar bagi perusahaan. Hipotesis alternatif ketiga yang diajukan dalam penelitian ini yaitu:

H3. Government ownership berpengaruh positif terhadap kinerja keuangan perusahaan

\section{Audit committee size dan Kinerja Perusahaan}

Komite audit berperan mengawasi jalannya kinerja dari dewan direktur terkait keuangan perusahaan. Perusahaan dengan komite audit yang kompeten memiliki probabilitas rendah mengalami skandal keuangan dan berkinerja buruk (Detthamrong et al., 2017). Menurut teori agensi, komite audit berperan penting dalam penerapan prinsip tata kelola perusahaan, meningkatkan kualitas informasi serta kinerja perusahaan. Berdasarkan studi empiris yang dilakukan oleh Aprinita (2016), A. Putra \& Nuzula (2017), dan Salehi et al. (2018) menyatakan bahwa audit committee size tidak berpengaruh terhadap kinerja perusahaan. Sementara Al-Okaily \& Naueihed (2019) menyatakan bahwa audit committee size dan kinerja keuangan memiliki pengaruh positif dan signifikan pada perusahaan non-keluarga, dan tidak memiliki pengaruh yang signifikan pada perusahaan keluarga. Sedangkan menurut Ofoeda (2017) dan Musallam (2020) menyatakan bahwa audit committee size yang besar berpengaruh positif dan signifikan terhadap kinerja perusahaan. Semakin besar proporsi ukuran komite audit akan meningkatkan kinerja perusahaan. Poporsi ukuran komite audit yang semakin besar akan mendorong terbentuknya struktur pengendalian intern yang memadai serta 
meningkatkan kualitas keterbukaan dalam pelaporan keuangan perusahaan (Aprinita, 2016). Hipotesis alternatif keempat yang diajukan dalam penelitian ini adalah:

H4. Audit committee size berpengaruh positif terhadap kinerja keuangan perusahaan.

\section{METODE PENELITIAN}

Penelitian ini merupakan termasuk dalam kategori penelitian asosiatif. Jenis penelitian asosiatif dilakukan untuk mencari hubungan antara satu variabel dengan variabel lain (Setiawan, 2016).

Populasi penelitian yaitu seluruh perusahaan BUMN pada periode 2014-2018 yang tercatat pada Bursa Efek Indoeisa (BEI). Sampel penelitian diambil menggunakan metode non-random sampling dengan teknik pengambilan sampel menggunakan purposive sampling. Metode tersebut dipilih dengan tujuan untuk mendapatkan sampel sesuai dengan kriteria yang telah ditentukan. Adapun kriteria pengambilan sampel antara lain 1) Perusahaan BUMN yang terdaftar di Bursa Efek Indonesia selama periode 2014-2018 secara berturut-turut. 2) Perusahaan BUMN menyampaikan laporan tahunan maupun laporan keuangan yang telah diaudit selama 2014-2018. 3) Perusahaan BUMN memiliki data lengkap mengenai board size, board independence, government ownership dan committee audite selama periode 2014-2018.
4) Perusahaan BUMN memiliki nilai ROA positif selama periode 2014-2018. Hasil estimasi sampel penelitian dapat disajikan pada tabel berikut:

Tabel 1: Kriteria Sampel Penelitian

\begin{tabular}{lc}
\hline \multicolumn{1}{c}{ Kriteria } & Jumlah \\
\hline Perusahaan BUMN yang terdaftar di & 16 \\
Bursa Efek Indonesia selama & \\
periode 2014-2018 secara berturut- & \\
turut & \\
Perusahaan BUMN yang tidak & $(0)$ \\
menyampaikan laporan tahunan & \\
maupun laporan keuangan yang & \\
telah diaudit selama 2014-2018 \\
Perusahaan BUMN yang tidak \\
memiliki data lengkap mengenai \\
board size, board independence, \\
government ownership dan \\
committee audite selama periode \\
2014-2018 \\
Perusahaan BUMN yang memiliki \\
nilai ROA negatif selama periode \\
2014-2018 \\
Perusahaan BUMN periode 2014- \\
2018 yang memenuhi kriteria \\
sampel penelitian
\end{tabular}

Sumber: laporan tahunan

\section{Definisi Operasional Variabel}

\section{Variabel Dependen}

Variabel dependen dalam penelitian ini yaitu profitabilitas perusahaan. Profitabilitas mencerminkan kinerja perusahaan selama periode tertentu. Salah satu indikator penting untuk memproksikan profitabilitas yaitu return on asset (Aprinita, 2016). Return On Asset (ROA) merupakan kemampuan perusahaan dalam menghasilkan laba dari total aset perusahaan. Semakin tinggi ROA menunjukkan kemampuan dalam memanfaatkan aktiva untuk menghasilkan 
laba bersih semakin efektif. Dalam penelitian ini, profitabilitas diproksikan dengan return on asset (ROA) (Zukaa Mardnly, 2018). return on asset (ROA) dapat dirumuskan sebagai berikut:

$$
R O A=\frac{\text { Total Income }}{\text { Total Asset }}
$$

\section{Variabel Independen}

Board Size atau ukuran dewan merupakan jumlah keseluruhan anggota dewan baik dewan komisaris maupun dewan direksi. Dewan komisaris merupakan sebuah organ pengendalian internal perusahaan yang bertujuan untuk mengawasi dan memberikan saran keseluruhan jalannya perusahaan agar sesuai dengan prinsip-prinsip GCG. Sedangkan untuk dewan direksi merupakan sebuah organ perusahaan yang bertanggungjawab atas pelaksanaan dari keseluruhan kegiatan perusahaan untuk kepentingan dan tujuan perusahaan. Dewan komisaris dan dewan direksi dipilih dan diberhentikan berdasarkan Rapat Umum Pemegang Saham (RUPS) dan Rapat Umum Pemegang Saham Luar Biasa (RUPSLB). Pengukuran operasional Board Size Jumlah keseluruhan anggota dewan perusahaan (Ehikioya, 2009), (Farooque et al., 2019), dan (Ahmed Haji, 2014).

\section{Board Independence merupakan} anggota dewan komisaris independen yang berasal dari luar perusahaan dan tidak terafiliasi dengan pihak internal perusahaan.
Dewan komisaris independen dalam menyatakan pendapatnya harus dapat objektif dan independen agar dapat mengurangi benturan konflik antara principals dan agent. Selain itu menurut prinsip GCG presentase dewan komisaris independen minimal $30 \%$ dari jumlah keseluruhan anggota dewan komisaris. Pengukuran board independence menurut (Rakesh Kumar Mishra, 2018) dan (Farooque et al., 2019).

$\frac{\text { Jumlah anggota komisaris independen }}{\text { Jumlah anggota komisaris }} \times 100 \%$

\section{Government ownership atau} kepemilikan pemerintah merupakan stukrut kepemilikan perusahaan atau pemegang saham yang berasal dari pemerintah sebagai wakil negara secara langsung. Presentase kepemilikan pemerintah yang besar maka dalam hal ini pemerintah memiliki peran yang besar juga dalam kegiataan operasional perusahaan serta bertanggungjawab mengelola perusahaan dengan tujuan mendapatkan laba untuk mensejahterahkan masyarakat. Pemerintah dalam perusahaan BUMN memiliki saham preferen atau seri A dwiwarna yang berarti pemerintah berhak mengelola dan mengatur perusahaan secara lagsung seperti mengangkat dan pemberhentikan dewan direksi atau komisaris. Pengukuran government ownership menurut (Darko et al., 2016).

$$
\frac{\text { Kepemilikan Pemerintah }}{\text { Jumlah Saham Beredar }} \times 100 \%
$$


Nominal: Barometer Riset Akuntansi dan Manajemen

P-ISSN: 2303-2065 E-ISSN: 2502-5430

Volume 10 No 1 (2021)

Committee audit atau komite audit adalah unsur tata kelola perusahaan yang dibentuk untuk membantu dewan komisaris dalam pengawasan seperti pengawasan terhadap sistem dan proses pelaporan keuangan, proses audit atas laporan keuangan perusahaan serta pengawasan kinerja teknis dan operasional serta pemenuhan ketentuan dan peratuan perundang undangan lainnya. Komite audit dibentuk oleh dewan komisaris dan dikepalai oleh komisaris independen serta anggota audit yang independen. Jumlah anggota komite audit minimal tiga orang dengan komisaris independen. Audit committee size diukur dari jumlah anggota komite audit (Darko et al., 2016), (Farooque, Buachoom and Sun, 2019) dan (Zukaa Mardnly, 2018).

\section{Metode Pengumpulan Data}

Data yang digunakan dalam penelitian ini adalah data sekunder karena mengacu pada informasi yang dikumpulkan dari sumber data yang telah ada. Data sekunder yang digunakan dalam penelitian ini yaitu jumlah anggota dewan komisiaris, jumlah anggota komisiaris independen, jumlah anggota dewan direksi, jumlah anggota komite audit, presentase kepemilikan pemerintah serta rasio profitabilitas yaitu ROA. Data-data perusahaan yang menjadi sampel tersebut diperoleh melalui tinjauan laporan tahunan perusahaan yang telah diaudit dan dipublikasi pada website resmi perusahaan terkait.

\section{Metode Analisis Data}

Metode analisis data yang digunakan dalam penelitian ini adalah regresi linier, model regresi penelitian ini adalah sebagai berikut:

$$
\begin{array}{ll}
\mathbf{R O A}= & \boldsymbol{\beta}_{\mathbf{0}}+\boldsymbol{\beta}_{1} \mathbf{B S}+\boldsymbol{\beta}_{2} \mathbf{B I}+\boldsymbol{\beta}_{3} \mathbf{G O}+\boldsymbol{\beta}_{4} \mathbf{A C S}+\boldsymbol{\varepsilon} \\
\text { ROA } & =\text { Profitabilitas } \\
\beta_{0} & =\text { Konstanta } \\
\beta_{1-4} & =\text { Koefisien Regresi } \\
\mathrm{BS} & =\text { Board Size } \\
\mathrm{BI} & =\text { Board Independence } \\
\mathrm{GO} & =\text { Government Ownership } \\
\mathrm{ACS} & =\text { Audit Committee Size } \\
\varepsilon & =\text { Kesalahan Residual (Error) }
\end{array}
$$

\section{HASIL PENELITIAN DAN PEMBAHASAN}

Penelitian ini bertujuan untuk memberikan bukti empiris mengenai pengaruh tata kelola perusahaan terhadap kinerja keuangan Badan Usaha Milik Negara (BUMN). Hasil estimasi model regresi menunjukkan bahwa model regresi ini mengalami masalah heteroskedastisitas dan autokorelasi. Untuk mengatasi masalah tersebut, maka dibutuhkan mekanisme robust standar error sebagai bentuk perbaikan terhadap model regresi. Robust standar error digunakan untuk melakukan adjustment terhadap standart error terhadap suatu model regresi tanpa menghilangkan 


\section{Nominal: Barometer Riset Akuntansi dan Manajemen \\ P-ISSN: 2303-2065 E-ISSN: 2502-5430 \\ Volume 10 No 1 (2021)}

heteroskedastisitas dan autokorelasi, sehingga penarikan kesimpulan secara statistik tetap dapat dilakukan. Berdasarkan robust standar error, estimasi final model regresi disajikan pada tabel berikut:

Tabel 2: Estimasi Final Model Regresi

\begin{tabular}{lcccc}
\hline Variabel & $\begin{array}{c}\text { Koefisien } \\
\text { Regresi }\end{array}$ & $\begin{array}{c}\text { Robust } \\
\text { Standard } \\
\text { Error }\end{array}$ & $\mathrm{T}_{\text {hitung }}$ & $\mathrm{P}>|\mathrm{t}|$ \\
\hline BS (X1) & 0.415 & 0.483 & 0.861 & 0.393 \\
BI (X2) & 0.083 & 0.084 & 0.979 & 0.332 \\
GO (X3) & 0.080 & 0.049 & -1.635 & 0.108 \\
ACS(X4) & 1.765 & 0.726 & 2.433 & $0.018^{*}$ \\
Konstanta & -2.720 & 7.367 & -0.369 & 13 \\
Prob>F & 0.000 & & & \\
$\mathrm{R}^{2}$ & 0.303 & & & \\
\hline
\end{tabular}

Sumber: Data diolah dengan SPSS (2020)

Keterangan: * artinya signifikansi pada asumsi tingkat signifikansi 5\%

\section{Goodness of Fit Model Regresi}

\section{Koefisien Determinasi}

Berdasarkan hasil olah data pada tabel 2 diperoleh nilai koefisien determinasi sebesar 0.303 atau 30,3 persen. Nilai koefisien determinasi menyimpulkan bahwa sebesar $30,3 \%$ variabilitas kinerja perusahaan dalam kurun waktu lima tahun dapat dijelaskan oleh variabel board size, board independence, government ownership dan audit committee size. Sementara sebesar $69,7 \%$ dipengaruhi oleh variabel lain diluar model.

\section{Uji Statistik F}

Hasil uji statistik F dalam penelitian ini menunjukkan kesimpulan bahwa variabel board size, board independence, government ownership dan audit committee size terbukti

secara simultan atau bersama-sama memiliki pengaruh terhadap variabel Return On Asset (ROA). Kesimpulan tersebut dapat dibuktikan dengan nilai Prob $>$ F (0.000) lebih rendah dari asumsi tingkat signifikansi $(\alpha=5 \%)$. Berdasarkan hasil Uji Statistik F membuktikan bahwa model regresi dalam penelitian ini telah terspesifikasi secara tepat.

\section{Uji Statistik t}

Dalam penelitian ini, hasil Uji Statistik t secara umum menyatakan bahwa variabel independen audit committee size mempunyai pengaruh signifikan atau bermakna terhadap variabel Return On Asset (ROA). Sementara variabel independen lainnya yang terdiri dari board size, board independence dan government ownership tidak memiliki pengaruh yang bermakna terhadap variabel Return On Asset (ROA). Hasil Uji Statistik t model regresi dapat diringkas melalui tabel berikut:

Tabel 3: Ringkasan Hasil Uji t

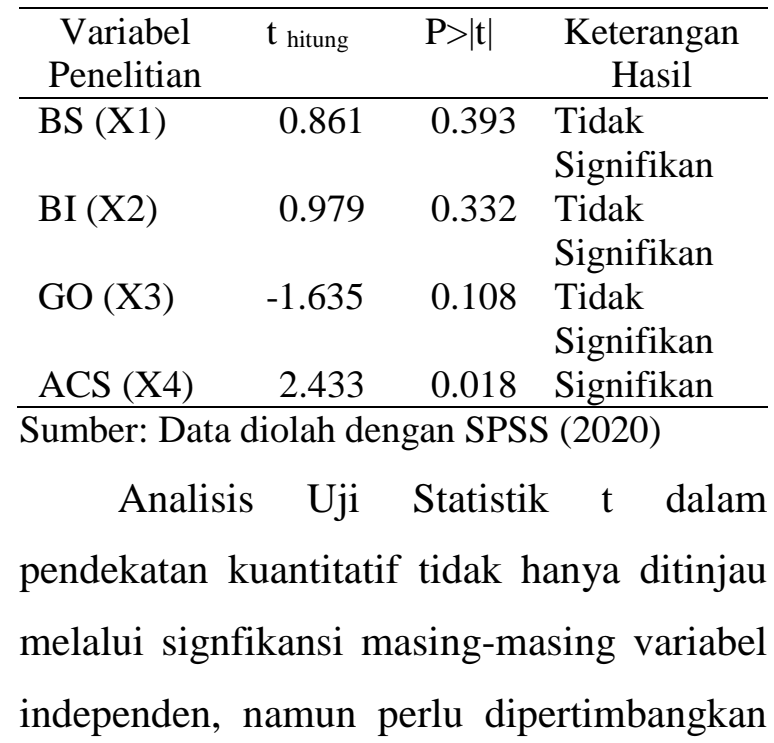




\section{Nominal: Barometer Riset Akuntansi dan Manajemen}

P-ISSN: 2303-2065 E-ISSN: 2502-5430

Volume 10 No 1 (2021)

pula kesesuaian hipotesis yang dibangun melalui kajian literatur. Analisis pengujian hipotesis alternative yang mengacu pada hasil estimasi Uji Statistik t dapat dijelaskan sebagai berikut:

\section{a. Hipotesis 1}

Hasil uji statistic $\mathrm{t}$ pada tabel 3 menunjukkan bahwa nilai $\mathrm{P}>|\mathrm{t}|$ yang diperoleh variabel board size sebesar 0.393 dengan nilai $t_{\text {hitung }}$ sebesar 0.861 . Nilai $t_{\text {hitung }}$ sebesar 0.861 menunjukkan bahwa arah koefisien dari variabel board size adalah positif. Nilai $\mathrm{P}>|\mathrm{t}| \quad \mathrm{Uji}$ Statistik $\mathrm{t}$ menunjukkan nilai $0.393>$ asumsi tingkat signifikansi $(\alpha=5 \%)$ yang berarti hipotesis pertama dalam penelitian ini ditolak. Hasil interpretasi hipotesis pertama dalam penelitian ini adalah tidak terbukti bahwa variabel board size secara parsial memiliki hubungan positif dan signifikan terhadap variabel Return On Asset (ROA).

\section{b. Hipotesis 2}

Hasil uji statistik $\mathrm{t}$ pada tabel 3 menunjukkan bahwa nilai $\mathrm{P}>|\mathrm{t}|$ yang diperoleh variabel board independence sebesar 0.332 dengan nilai $\mathrm{t}$ hitung sebesar 0.979. Nilai $\mathrm{t}$ hitung sebesar 0.979 menunjukkan bahwa arah koefisien dari variabel board independence adalah positif. Nilai $\mathrm{P}>|\mathrm{t}|$ Uji Statistik t menunjukkan nilai $0.332>$ asumsi tingkat signifikansi $(\alpha=5 \%)$ yang berarti hipotesis kedua dalam penelitian ini ditolak. Hasil interpretasi hipotesis kedua dalam penelitian ini adalah tidak terbukti bahwa variabel board independence secara parsial memiliki hubungan positif dan signifikan terhadap variabel Return On Asset (ROA).

\section{c. Hipotesis 3}

Hasil uji statistik t pada tabel 3 menunjukkan bahwa nilai $\mathrm{P}>|\mathrm{t}|$ yang diperoleh variabel government ownership sebesar 0.108 dengan nilai $\mathrm{t}$ hitung sebesar 1.635. Nilai $\mathrm{t}$ hitung sebesar -1.635 menunjukkan bahwa arah koefisien dari variabel government ownership adalah negatuf. Nilai $\mathrm{P}>|\mathrm{t}| \quad \mathrm{Uji}$ Statistik $\mathrm{t}$ menunjukkan nilai $0.108>$ asumsi tingkat signifikansi $(\alpha=5 \%)$ yang berarti hipotesis ketiga dalam penelitian ini ditolak. Hasil interpretasi hipotesis ketiga dalam penelitian ini adalah tidak terbukti bahwa variabel government ownership secara parsial memiliki hubungan positif dan signifikan terhadap variabel Return On Asset (ROA).

\section{d. Hipotesis 4}

Hasil uji statistic $\mathrm{t}$ pada tabel 3 menunjukkan bahwa nilai $\mathrm{P}>|\mathrm{t}|$ yang diperoleh variabel audit committee size sebesar 0.018 dengan nilai $\mathrm{t}$ hitung sebesar 2.433. Nilai $\mathrm{t}$ hitung sebesar 2.433 menunjukkan bahwa arah koefisien dari variabel audit committee size adalah positif. Nilai $\mathrm{P}>|\mathrm{t}|$ Uji Statistik t menunjukkan nilai $0.018>$ asumsi tingkat signifikansi $(\alpha=5 \%)$ yang berarti hipotesis keempat dalam 


\section{Nominal: Barometer Riset Akuntansi dan Manajemen}

P-ISSN: 2303-2065 E-ISSN: 2502-5430

Volume 10 No 1 (2021)

penelitian ini diterima. Hasil interpretasi hipotesis keempat dalam penelitian ini adalah terbukti bahwa variabel audit committee size secara parsial memiliki hubungan positif dan signifikan terhadap variabel Return On Asset (ROA).

\section{Board Size dan Kinerja Perusahaan}

Hasil estimasi model regresi dan hasil Uji Statistik $t$ penelitian ini menyatakan bahwa board size memiliki hubungan positif dan tidak signifikan terhadap kinerja perusahaan. Kesimpulan tersebut dibuktikan dengan nilai $\mathrm{P}>|\mathrm{t}|$ sebesar 0.393 yang berarti tidak memiliki pengaruh secara signifikan. Nilai koefisien regresi sebesar 0.861 yang menunjukkan bahwa variabel board size memiliki hubungan positif terhadap kinerja perusahaan. Penelitian ini menyimpulkan bahwa nilai board size tidak memiliki pengaruh terhadap kinerja perusahaan yang diukur melalui perbandingan laba bersih dengan asset perusahaan. Hasil tidak signifikan yang diperoleh memgindikasikan bahwa penelitian ini tidak menemukan bukti yang cukup mengenai peran board size sebagai kolateral ketika perusahaan akan meningkatkan kinerja perusahaan. Pengaruh yang tidak signifikan menunjukkan bahwa kinerja perusahaan tidak ditentukan oleh jumlah atau ukuran dewan dalam suatu perusahaan.

Hasil penelitian ini tidak sesuai dengan Mohamed et al. (2016) dan Pavić Kramarić et al. (2018) yang menyatakan bahwa board size memiliki pengaruh negatif dan signifikan terhadap kinerja perusahaan yang diproksikan melalui return on asset. Namun, hubungan positif antara board size dan kinerja keuangan perusahaan sejalan dengan hasil penelitian Rashid (2018) yang menunjukkan bahwa board size dan kinerja keuangan memiliki hubungan positif dan tidak signifikan pada asumsi tingkat signifikansi 5\% dan hasil penelitian Salehi et al. (2018) yang menyatakan bahwa terdapat hubungan positif antara board size dan kinerja keuangan perusahaan. Pengaruh positif menunjukan bahwa semakin banyak ukuran dewan maka kinerja perusahaan cenderung meningkat. Hal ini berkaitan dengan Resources Dependence Theory (RDT) bahwa semakin banyak anggota dewan maka semakin banyak pengalaman atau pengetahun dan akses sumber daya yang dimiliki perusahaan BUMN. Resources dependence theory (RDT) meramalkan bahwa semakin banyak posisi yang dipegang oleh direksi akan memberikan lebih banyak akses sumber daya bagi perusahaan yang mengarah pada kinerja yang unggul (Mishra \& Kapil, 2018). Dilihat dari konsep teori agensi, semakin besar ukuran dewan akan meningkatkan fungsi pemantauan dan monitoring terhadap manjemen sehingga manajemen akan selalu bertindak sesuai dengan kepentingan pemilik, oleh karena itu 
Nominal: Barometer Riset Akuntansi dan Manajemen

P-ISSN: 2303-2065 E-ISSN: 2502-5430

Volume 10 No 1 (2021)

akan memberikan kontribusi positif terhadap kinerja perusahaan (Unda et al., 2019).

\section{Board Independence dan Kinerja Perusahaan}

Hasil estimasi model regresi dan hasil Uji Statistik $\mathrm{t}$ penelitian ini menyatakan bahwa board independence memiliki hubungan positif dan tidak signifikan terhadap kinerja perusahaan. Kesimpulan tersebut dibuktikan dengan nilai $\mathrm{P}>|\mathrm{t}|$ sebesar 0.332 yang berarti tidak memiliki pengaruh secara signifikan. Nilai koefisien regresi sebesar 0.979 yang menunjukkan bahwa variabel board independence memiliki hubungan positif terhadap kinerja perusahaan. Hasil yang tidak signifikan memberikan tidak cukup bukti mengenai korelasi board independence dengan kinerja keuangan perusahaan.

Pengaruh yang tidak signifikan antara board independence dan kinerja perusahaan berlawanan dengan temuan Merendino et al. (2019), Johl et al. (2015), dan Palaniappan G. (2017) yang menyatakan bahwa terdapat pengaruh yang signifikan antara board independence dan kinerja perusahaan. Hasil penelitian ini sejalan dengan Petchsakulwong \& Jansakul (2017) dan Mohamed et al. (2016) bahwa board independence memiliki hubungan positif terhadap kinerja perusahaan. Sejalan dengan konsep teori agensi, perusahaan menunjuk dewan independen untuk memantau kinerja agent dalam mencapai kepentingan pemegang saham (Faatihah et al., 2016). Dewan independen yang ditunjuk akan melakukan monitoring terhadap manajer secara efektif untuk mengurangi biaya agensi (Mishra \& Kapil, (2018). Dengan demikian, semakin besar jumlah dewan independen akan meningkatkan kinerja keuangan perusahaan.

\section{Government Ownership dan Kinerja}

\section{Perusahaan}

Pada hasil estimasi model regresi dan hasil Uji Statistik t penelitian ini menyatakan bahwa kepemilikan pemerintah memiliki hubungan negatif dan tidak signifikan terhadap kinerja perusahaan. Argumen tersebut dibuktikan dengan nilai $\mathrm{P}>|\mathrm{t}|$ sebesar 0.108 bahwa tidak memiliki pengaruh secara signifikan. Nilai koefisien regresi sebesar 1.635 yang menunjukkan bahwa variabel kepemilikan pemerintah memiliki hubungan negatif terhadap kinerja perusahaan. Temuan ini tidak sesuai dengan temuan Mohd Ghazali (2012) dan Ahmed Haji (2014) yang menyatakan bahwa terdapat hubungan positif antara kepemilikan pemerintah dan kinerja keuangan perusahaan. Arah pengaruh negatif antara kepemilikan pemerintah dengan kinerja keuangan perusahaan sejalan dengan pernyataan Angela et al. (2019). Menurut Darko et al. (2016), kepemilikan pemerintah kurang dari $20 \%$ cenderung berkinerja lebih baik daripada kepemilikan 


\section{Nominal: Barometer Riset Akuntansi dan Manajemen}

P-ISSN: 2303-2065 E-ISSN: 2502-5430

Volume 10 No 1 (2021)

pemerintah yang lebih daripada $40 \%$. Hal ini dikarenakan bahwa pemerintah atau negara belum memiliki kemampuan untuk mengelola sebuah perusahaan publik.

Berdasarkan konsep agency theory, menyatakan bahwa terdapat perbedaan kepentingan antara pemerintah dan pemegang saham lainnya. Dimana pemegang saham non-pemerintah berharap perusahaan BUMN dapat menambah kekayaan pemegang saham, namun hal ini berbeda dengan pemerintah yang memiliki kepentingan sosial dan politik. Berbeda dengan perusahaan swasta pada umumnya, perusahaan BUMN memiliki tujuan lain selain menghasilakan profit, yaitu turut mengemban tanggungjawab untuk mensejahterahkan masayrakat. Hubungan negatif antara kepemilikan pemerintah dan kinerja keuangan perusahaan mengindikasikan bahwa adanya kepemilikan pemerintah yang semakin besar berdampak pada semakin buruknya kinerja perusahaan karena pemerintah dianggap belum mampu mengelola perusahaan secara baik, sehingga kinerja perusahaan semakin lambat atau bahkan terjadi penurunan (Angela et al., 2019).

\section{Audit committee size Size dan Kinerja} Perusahaan

Pada penelitian hasil estimasi model regresi dan hasil Uji Statistik t penelitian ini menyatakan bahwa ukuran komite audit memiliki hubungan positif dan signifikan terhadap kinerja perusahaan. Hal tersebut dibuktikan dengan nilai $\mathrm{P}>|\mathrm{t}|$ sebesar 0.018 yang berarti memiliki pengaruh secara signifikan. Nilai koefisien regresi sebesar 2.433 yang menunjukkan bahwa variabel ukuran komite audit memiliki hubungan positif terhadap kinerja perusahaan. Berbeda dengan penelitian sebelumnya, A. Putra \& Nuzula (2017), dan Salehi et al. (2018) menyatakan bahwa audit committee size tidak berpengaruh terhadap kinerja perusahaan. Namun, hasil penelitian ini sesuai dengan temuan Ofoeda (2017) dan Musallam (2020) menyatakan bahwa audit committee size mempunyai hubungan positif dan signifikan terhadap kinerja keuangan perusahaan.

Berdasarkan konsep agency theory, komite audit dalam struktur tata kelola dikembangkan guna melakukan pengawasan dan pemantauan untuk mengatasi masalah agensi antara pemilik perusahaan dengan manajer (Al-Okaily \& Naueihed, 2019). Poporsi ukuran komite audit yang semakin besar akan mendorong terbentuknya struktur pengendalian intern yang memadai serta meningkatkan kualitas keterbukaan dalam pelaporan keuangan perusahaan (Aprinita, 2016). Lebih lanjut Detthamrong, Chancharat and Vithessonthi (2017) menjelaskan bahwa komite audit yang berkompeten akan menurunkan resiko 
perusahaan mengalami skandal keuangan, sehingga probabilitas perusahaan berkinerja buruk semakin rendah. Dengan demikian semakin besar proporsi ukuran komite audit akan meningkatkan kinerja perusahaan.

\section{SIMPULAN DAN SARAN}

Hasil penelitian ini memberikan bukti mengenai urgensi komite audit dalam tata kelola perusahaan terutama pada Badan Usaha Milik Negara (BUMN). Hal ini dapat dibuktikan dengan adanya estimasi positif signifikan antara audit committee size dengan kinerja keuangan perusahaan. Penelitian ini juga menunjukan bahwa board size, board independence serta kepemilikan pemerintah tidak memiliki peran dalam menjelaskan variabilitas kinerja keuangan Badan Usaha Milik Negara (BUMN).

Penelitian ini hanya mempertimbangkam aspek tata kelola perusahaan dari segi board size, board independence, government ownership dan audit committee size. Penelitian selanjutnya disarankan untuk mempertimbangkan aspek moderasi dari kondisi perekonomian serta bias kognitif para pengambil keputusan, misalnya managerial overconfidence.

\section{DAFTAR PUSTAKA}

Ahmed Haji, A. (2014). The relationship between corporate governance attributes and firm performance before and Some Malaysian evidence.
https://doi.org/10.1108/IJCoMA-022012-0009

Akbar, S., Poletti-hughes, J., El-faitouri, R., Zulfiqar, S., \& Shah, A. (2016). More on the Relationship between Corporate Governance and Firm Performance in the UK: Evidence from the Application of Generalized Method of Moments Estimation. Research in International Business and Finance, 1-36. https://doi.org/10.1016/j.ribaf.2016.03. 009

Al-Okaily, J., \& Naueihed, S. (2019). Audit committee effectiveness and family firms: impact on performance. Management Decision, 58(6), 10211034. https://doi.org/10.1108/MD-042018-0422

Angela, J., Jessica, M., Rinaningsih, R., \& Haryono, L. (2019). Pengaruh Kepemilikan Pemerintah terhadap Kinerja Perusahaan Badan Usaha Milik Negara yang Terdaftar di BEI. Studi Akuntansi Dan Keuangan Indonesia, 2(2), 55-75. https://doi.org/10.21632/saki.2.2.203223

Aprinita, B. S. (2016). Pengaruh Good Corporate Governance Terhadap Kinerja Keuangan Pada Perusahaan Sektor Consumer Goods Yang Terdaftar Di Bursa Efek Indonesia Tahun 2012-2014. Jurnal Bisnis Dan Manajemen, 52(11), 32-53.

Azis, A., \& Hartono, U. (2017). Pengaruh Good Corporate Governance, Struktur Modal, Dan Leverage Terhadap Kinerja Keuangan Perusahaan Pada Sektor Pertambangan Yang Terdaftar Di Bursa Efek Indonesia Tahun 2011-2015. Jurnal Lmu Manajemen, 5(3), 1-13.

Buallay, A., Hamdan, A., \& Zureigat, Q. (2017). Corporate Governance and Firm Performance: Evidence from Saudi Arabia Corporate Governance and Firm 
Performance: Evidence from Saudi. Australian Accounting, Business and Finance Journal, 11(1), 78-98. https://doi.org/10.14453/aabfj.v11i1.6

Buchdadi, A. D., Hadistira, V., \& Kurnianti, D. (2019). Pengaruh Board Size, Board Independence dan Ownership Structure Terhadap Kebijakan Dividen Pada Sektor Manufaktur Yang Terdaftar Di Bursa Efek Indonesia (BEI) Periode 2012-2016. Jurnal Riset Manajemen Sains Indonesia (JRMSI_, 10(1), 169185.

Carlton, D. W., \& Perloff, J. M. (2015). Modern Industrial Organization (4th ed.). Pearson Education.

Ciftci, I., Tatoglu, E., Demirbag, M., \& Zaim, S. (2019). Corporate Governance and Firm Performance in Emerging Markets: Evidence From Turkey. International Business Review, 28, 90103.

https://doi.org/10.1016/j.ibusrev.2018.0 8.004

Darko, J., Aribi, Z. A., Uzonwanne, G. C., Darko, J., Aribi, Z. A., \& Uzonwanne, G. C. (2016). Corporate governance: the impact of director and board structure, ownership structure and corporate control on the performance of listed companies on the Ghana stock exchange. https://doi.org/10.1108/CG11-2014-0133

Detthamrong, U., Chancharat, N., \& Vithessonthi, C. (2017). Research in International Business and Finance Corporate Governance , Capital Structure and Firm Performance: Evidence from Thailand. Research in International Business and Finance, 42, 689-709.

https://doi.org/10.1016/j.ribaf.2017.07. 011

Ehikioya, B. I. (2009). Corporate governance structure and firm performance in developing economies: evidence from Nigeria. 9(3), 231-243. https://doi.org/10.1108/1472070091096 4307

Faatihah, S., Fuzi, S., Abdul, A., \& Julizaerma, M. K. (2016). Board Independence and Firm Performance. Procedia Economics and Finance, 37(16), 460-465. https://doi.org/10.1016/S22125671(16)30152-6

Farooque, O. Al, Buachoom, W., \& Sun, L. (2019). Board, Audit Committee , Ownership and Financial PerformanceEmerging Trends From Thailand. Pacific Accounting Review, 32(1), 5481. https://doi.org/10.1108/PAR-102018-0079

Cegah Korupsi, Sri Mulyani Desak BUMN Perbaiki Tata Kelola. https://www.cnnindonesia.com/ekonom i/20191004135706-92-436746/cegahkorupsi-sri-mulyani-desak-bumnperbaiki-tata-kelola

Indonesia, P. (2003). Undang-Undang Republik Indonesia Nomor 19 Tahun 2003.

Jensen, M. C., \& Meckling, W. H. (1976). Theory of The Firm: Managerial Behavior, Agency Costs and Ownership Structure. Journal of Financial Economics, 3(4), 305-360. https://doi.org/10.1016/0304405X(76)90026-X

Johl, S. K., Kaur, S., \& Cooper, B. J. (2015). Board Characteristics and Firm Performance: Evidence from Malaysian Public Listed Firms. Journal of Economics, Business and Management, 3(2), 239-243. https://doi.org/10.7763/joebm.2015.v3. 187

Kao, M. F., Hodgkinson, L., \& Jaafar, A. (2019). Ownership structure, board of 
directors and firm performance: evidence from Taiwan. Corporate Governance (Bingley), 19(1), 189-216. https://doi.org/10.1108/CG-04-20180144

Larcker, D., \& Tayan, B. (2016). Corporate Governance Matters: A Closer Look at Organizational Choices and Their Consequences (2nd ed.). Pearson Education.

Merendino, A., \& Melville, R. (2019). The board of directors and fi rm performance: empirical evidence from listed companies. The International Journal of Business in Society, 1-45. https://doi.org/10.1108/CG-06-20180211

Miles, J. A. (2012). Management and Organization Theory: a Jossey-Bass reader (1st ed.). Jossey-Bass A Wiley Imprint.

Mishra, R. K., \& Kapil, S. (2018). Board characteristics and firm value for Indian companies. Journal of Indian Business Research, 10(1), 2-32. https://doi.org/10.1108/JIBR-07-20160074

Mohamed, S., Ahmad, K., \& Khai, K. (2016). Corporate Governance Practices and Firm Performance : Evidence from Top 100 Public Listed Companies in Malaysia. Procedia Economics and Finance, 35, 287-296. https://doi.org/10.1016/S22125671(16)00036-8

Mohd Ghazali, N. A. (2012). Ownership structure, corporate governance and corporate performance in Malaysia. https://doi.org/10.1108/1056921101105 7245

Musallam, S. R. M. (2020). Effects of board characteristics, audit committee and risk management on corporate performance: evidence from Palestinian listed companies. International Journal of Islamic and Middle Eastern Finance and Management. https://doi.org/10.1108/IMEFM-122017-0347

Ofoeda, I. (2017). Corporate governance and non-bank financial institutions profitability. International Journal of Law and Management, 59(6), 854-875. https://doi.org/10.1108/ijlma-05-20160052

Palaniappan, G. (2017). Determinants of corporate financial performance relating to board characteristics of corporate governance in Indian manufacturing industry: An empirical study. European Journal of Management and Business Economics, 26(1), 67-85. https://doi.org/10.1108/EJMBE-072017-005

Pavić Kramarić, T., Aleksic, A., \& PejicBach, M. (2018). Measuring the impact of board characteristics on the performance of Croatian insurance companies. International Journal of Engineering Business Management, 10, $1-13$.

https://doi.org/10.1177/1847979018765 864

Undang-Undang Republik Indonesia Tentang Badan Usaha Milik Negara, Pub. L. No. 19, 54 (2003).

Petchsakulwong, P., \& Jansakul, N. (2017). Board of Directors and Profitability Ratio of Thai Non-life Insurers. Kasetsart Journal of Social Sciences, 17. https://doi.org/10.1016/j.kjss.2017.11.0 05

Pfeffer, J. (1972). Size And Composition of Corporate Boards of Directors: The Organization And Its Environment. Corporate Governance: Values, Ethics and Leadership, 17(2), 218-228. https://doi.org/10.2307/2393956 
Pfeffer, J., \& Salancik, G. R. (1978). The External Control of Organizations: A Resource Dependence Approach. In NY: Harper and Row Publishers. https://doi.org/10.2307/2392573

Putra, A., \& Nuzula, N. (2017). Pengaruh Corporate Governance Terhadap Profitabilitas (Studi Pada Perusahaan Perbankan yang Terdaftar di Bursa Efek Indonesia Periode 2013-2015). Jurnal Administrasi Bisnis, 47(1), 103-112.

Putra, B. P. D. (2015). Pengaruh Dewan Komisaris, Proporsi Komisaris Independen, Terhadap Kinerja Perusahaan. Jurnal Manajemen Teori Dan Terapan, 8(2), 70-85.

Rakesh Kumar Mishra. (2018). Board characteristics and fi $\mathrm{rm}$ value for Indian companies. https://doi.org/10.1108/JIBR-07-20160074

Rashid, A. (2018). Board Independence and Firm Performance: Evidence From Bangladesh. Future Business Journal, 4 , $34-49$. https://doi.org/10.1016/j.fbj.2017.11.00 3

Salehi, M., Tahervafaei, M., \& Tarighi, H. (2018). The effect of characteristics of audit committee and board on corporate profitability in Iran. Journal of Economic and Administrative Sciences, 34(1), 71-88. https://doi.org/10.1108/jeas-04-20170017

Setiawan, A. (2016). Pengaruh Corporate Governance Terhadap Kinerja Keuangan Perusahaan. Jurnal SIKAP (Sistem Informasi, Keuangan, Auditing Dan Perpajakan), 1(1), 1-8. https://doi.org/10.32897/sikap.v1i1.41

Taouab, O., \& Issor, Z. (2019). Firm Performance: Definition and Measurement Models. European
Scientific Journal ESJ, 15(1), 93-106. https://doi.org/10.19044/esj.2019.v15n $1 \mathrm{p} 93$

Unda, L. A., Ahmed, K., \& Mather, P. R. (2019). Board characteristics and creditunion performance. Accounting and Finance, 59(4), 137-154. https://doi.org/10.1111/acfi.12308

Utami, D. W., \& Giovanni, A. (2020). Financial Distress Phenomenon of Nonfinancial Companies in Indonesia. Relevance: Journal of Management and Business, 3(2), 175-188.

Wardani, D. K., \& Juliani. (2018). The Effect of Tax Avoidance on Company Value With Corporate Governance As Moderating Variables. Jurnal NOMINAL, 7(2), 47-61.

Zhou, H., Ansah, S. O., \& Maggina, A. (2018). Board of Directors, Audit Committee, and Firm Performance: Evidence from Greece. Journal of International Accounting, Auditing and Taxation, 1-46. https://doi.org/10.1016/j.intaccaudtax.2 018.03 .002

Zhou, K. Z., Gao, G. Y., \& Zhao, H. (2017). State Ownership and Firm Innovation in China: An Integrated View of Institutional and Efficiency Logics. Administrative Science Quarterly, 62(2), 1-30. https://doi.org/10.1177/0001839216674 457

Zukaa Mardnly. (2018). International Journal of Islamic and Middle Eastern Finance and Management. Managerial Finance, 34(10). https://doi.org/10.1108/mf.2008.00934j aa.001 